\title{
Vegetation and soil properties in restored wetlands near Lake Taihu, China
}

\author{
Jinwei Lu · Hongjun Wang • Weidong Wang • \\ Chengqing Yin
}

(C) Springer Science+Business Media B.V. 2007

\begin{abstract}
Riparian wetlands are important components of the lake ecosystem, and they play essential roles in maintaining system health. Remediation of degraded lakeshore wetlands is an essential component of lake restoration. A study was conducted to investigate the restoration of lakeshore wetlands, which were converted to rice fields and then abandoned for 2, 5, 10 and 15 years, near Lake Taihu. Soil samples $(0-20 \mathrm{~cm}$ and $20-40 \mathrm{~cm}$ ) were taken and plant species were investigated. The carbon content in the soil had increased significantly, rising from $0.71 \%$ to $1.85 \%$ between 2 and 15 years. Organic matter accumulation improved soil texture, and water stable aggregate content $(>0.25 \mathrm{~mm})$ and soil
\end{abstract}

Guest editors: B. Qin, Z. Liu \& K. Havens

Eutrophication of shallow lakes with special reference to Lake Taihu, China

J. Lu $\cdot$ H. Wang $\cdot$ W. Wang $\cdot$ C. Yin $(\varangle)$

SKLEAC, the Research Center for Eco-

Environmental Sciences, Chinese Academy of

Sciences, Beijing 100085, China

e-mail: cqyin@263.net

\section{J. Lu $\cdot$ H. Wang}

Graduate School of the Chinese Academy Sciences, Beijing 100039, China

C. Yin

Northeast Institute of Geography and Agricultural Ecology, CAS, Jinlin Province, Changchun 130000, China porosity increased. Total nitrogen in the soil increased from $0.06 \%$ to $0.13 \%$, and total Kjeldahl nitrogen increased from $124.4 \mathrm{mg} \mathrm{kg}^{-1}$ to $351.5 \mathrm{mg} \mathrm{kg}^{-1}$. Total phosphorus in the soil increased from $0.045 \%$ to $0.071 \%$, and the Olsen- $P$ value increased from $5.13 \mathrm{mg} \mathrm{kg}^{-1}$ to $16.0 \mathrm{mg} \mathrm{kg}{ }^{-1}$. Results showed that phosphorous did not increase as much as nitrogen. In the vegetation restoration process, plant species composition moved towards a natural wetland community, and spatial heterogeneity and landscape diversity increased. The richness of plant biodiversity increased rapidly in the first 2 years, then more slowly in later restoration stages. The wetlands recovery process may be complicated by interactions of biota and soil and hydrological conditions.

Keywords Lakeshore - Wetlands .

Restoration · Dynamics · Process .

Vegetation · Soil nutrients - Lake Taihu

\section{Introduction}

Eutrophication in lakes and reservoirs is a worldwide environmental problem (Vollenweider, 1992), particularly since the 1980s in China due to rapid economic development (Jin et al., 1990). Riparian wetlands are important components of the lake ecosystem, and they play essential roles 
for maintaining system health (Naiman \& Décamps, 1997). These wetlands are effective buffers, retaining water and nutrients, improving water quality, and providing diverse and dynamic habitats for wildlife (Naiman et al., 1994; Yin \& Lan, 1995; Tabacchi et al., 1998; Coveney et al., 2002). Therefore, remediation and restoration of lakeshore wetlands is an essential component of lake restoration.

Due to historical lack of recognition of the ecological value of riparian wetlands, many wetlands were destroyed in the last 50 years. Most of the destruction is a result of conversion to agriculture and other economic uses (National Bureau of Statistics of China, 2001; Chen \& Chen, 2002). Approximately $160 \mathrm{~km}^{2}$ of riparian areas are cultivated along Lake Taihu ( $\mathrm{Hu} \&$ Jiang, 2004; Xiong, 2004). Losing the buffering capacity of riparian zones enhanced eutrophication, and, in recent years, wetland restoration has been implemented extensively in China (Chen, 2001). Hydrology, soil, and vegetation are interconnected components of wetlands and undergo dynamic changes during restoration. This paper describes soil and vegetation changes in the riparian wetlands and discusses the effectiveness and feasibility of natural restoration. This information will be useful for future wetland restoration efforts.

\section{Study area, materials and methods}

\section{Description of study area}

The study area is located at the lakeshore of northeast Lake Taihu. The land in this region is flat with adjacent undulating steep hills. Natural riparian wetlands were changed into paddy fields and other agricultural uses from the 1960's to 1980 's. After 1988, with a local policy for protecting the lake and an increase in labor costs, some paddy fields were abandoned. Vegetation recolonized these paddy fields, and the weir was destroyed, allowing water to move freely into the wetlands. In investigation years 2003 and 2004, the lake water table was low, so the wetlands were not inundated.
Field investigation and sampling

\section{Experiment design}

Five sections of paddy fields, with an area $\sim 0.15$ ha and an age series of 2-, 5-, 10-, and 15years since abandonment, and a reference wetland were selected in the riparian areas of Lake Taihu in the Dafu Town of Wuxi (Fig. 1). Since it was difficult to find an undisturbed natural wetland as a reference site, an uncultivated and less disturbed 30-year old riparian wetland was chosen. All of the abandoned lands in the study areas were flat and subject to similar hydrological conditions. The age of abandoned sites were

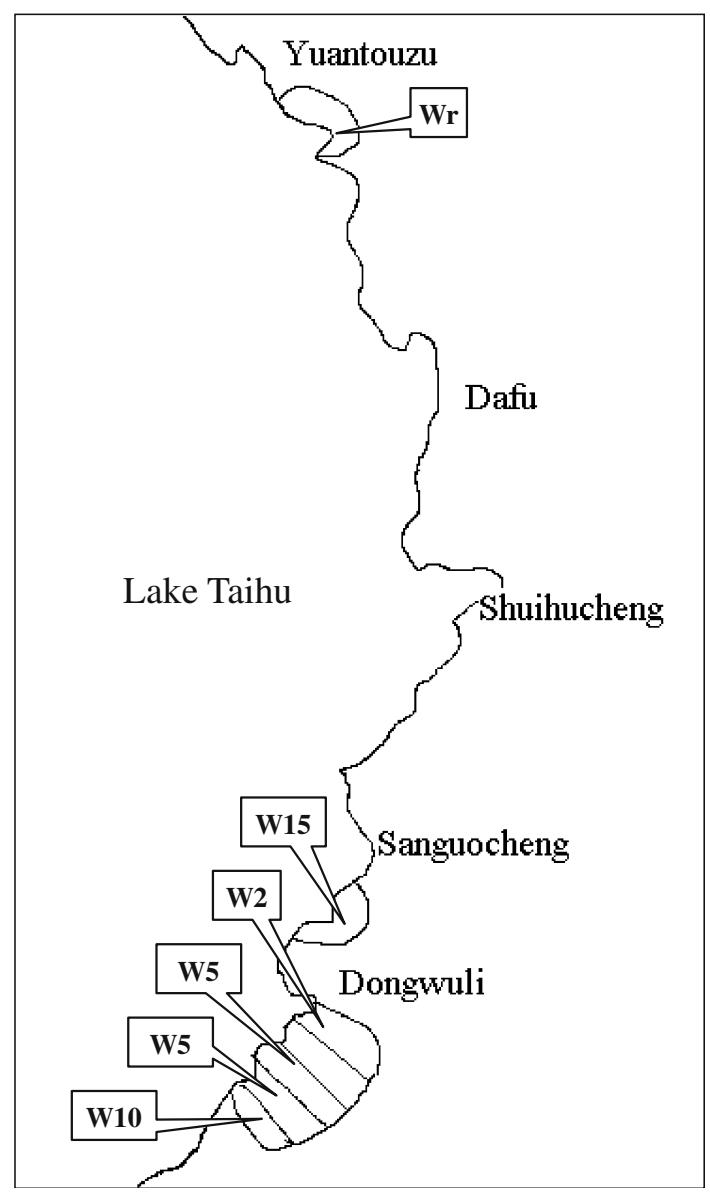

Fig. 1 Map of the distribution of restored wetlands in the studied area in Lake Taihu. Numbers refer to the numbers of years after they were abandoned as rice fields. W indicates wetland, and $\mathrm{Wr}$ indicates reference wetland 
determined from field surveys and interviews with local landowners. Each wetland was numbered according to the time since abandonment as paddy fields (e.g. W5 indicates a wetland in its fifth year or growing season since abandonment as a paddy field). Wr means reference wetland.

\section{Investigation and measurement of restored vegetation}

Vegetation plays a critical role in wetland restoration and may indicate wetland value and function. In 2003 and 2004, four vegetation investigations were conducted in five different wetlands. Belts were identified according to vegetation characteristics. Six $1 \times 1 \mathrm{~m}$ quadrats were chosen randomly in each wetland belt. Species, coverage, diversity and biomass were recorded in each quadrat every three months from March to October. Six $0.5 \times 0.5 \mathrm{~m}$ quadrats also were chosen for ratio analysis of biomass between upland and low land parts in the same season. Height and density of the dominant vegetation were measured in three of these quadrats selected at random (Song, 2001). Data on hydrology, vegetation, soil and other conditions in the study area were collected as reference.

\section{Soil analysis}

Soil was collected from five wetlands in different stages of restoration. Three to five sample sites were selected in each vegetation belt. The soil profile was divided into two horizontal layers: 0$20 \mathrm{~cm}$ and $20-40 \mathrm{~cm}$, and five samples were collected at each sampling site. Soil samples were air-dried and hand-sieved through a 20-mesh sieve screen to remove roots and debris. Sieved soil samples were sealed in a plastic bag for $\mathrm{pH}$, biologically available $\mathrm{N}$, and Olsen-P analysis. Remaining soil was crushed and sieved through a 100-mesh sieve screen, then stored for soil organic matter (SOM), total $\mathrm{N}(\mathrm{TN})$, and total $\mathrm{P}$ (TP) analysis. Soil bulk density and porosity were evaluated with a cutting ring. All soil samples were analyzed with standard methods for soil analysis (Soil Science Society of America and American Society of Agronomy, 1996).

\section{Statistical analysis}

Locating sites abandoned for different periods of time but similar characteristics is difficult. Therefore, data interpretation techniques for the four durations of abandonment were used. While the experiments were pseudo-replicates, the distance between sampling sites was sufficient to ensure adequate variation within each site.

Similarities among communities at each site and the reference natural wetland were determined using the Sorensen similarity coefficient (SC) (Song, 2001) calculated as $\mathrm{SC}=2 \omega /(a+b)$, where $\omega$ is the number of species found in both the natural and a given abandoned site; $a$ is the total number of species found in the reference natural wetland, and $b$ is the total number of species found in a given abandoned site. SAS software was used to analyze experimental data, and all significant differences are at a probability of 0.05 or less, unless otherwise noted.

\section{Results}

$\mathrm{C}, \mathrm{N}$, and $\mathrm{P}$ changes in restored wetlands soil

An increasing trend was observed for TOC, $\mathrm{TN}, \mathrm{KN}, \mathrm{TP}$, and Olsen-P content along the succession gradient defined by 2-, 5-, 10-, and 15 -year-old paddy field abandonment sites and the reference wetland. TOC ranged from $0.73 \%$ to $2.76 \%$ in the $0-20 \mathrm{~cm}$ layer and $0.31-0.46 \%$ in the $20-40 \mathrm{~cm}$ layer (Fig. 2). There was lower

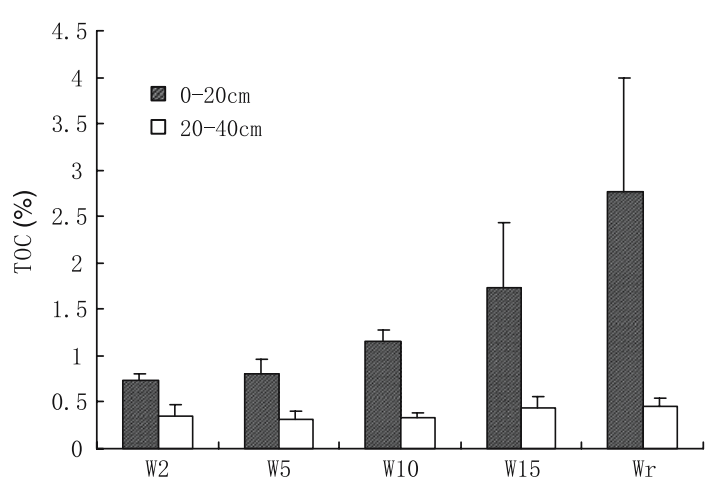

Fig. 2 Changes of soil Organic $\mathrm{C}$ in different restored wetlands 
TOC content in the 2- to 5-year periods and higher content in the 10- to 15 -year period and lay obvious accumulation of TOC at 0-20 cm layer. One-way ANOVA showed a significant difference in the $0-20 \mathrm{~cm}$ layer, but not in the $20-40 \mathrm{~cm}$ layer.

TN and $\mathrm{KN}$ ranged from $0.039 \%$ to $0.098 \%$ and $124.35 \mathrm{mg} \mathrm{kg}^{-1}$ to $351.48 \mathrm{mg} \mathrm{kg}^{-1}$, respectively, in the $0-20 \mathrm{~cm}$ layer and $0.020-0.044 \%$ and $52.5-83.1 \mathrm{mg} \mathrm{kg}^{-1}$, respectively, in the $20-40 \mathrm{~cm}$ layer (Fig. 3). There lay while an obvious decrease trend of $\mathrm{TN}$ content in the earlier restoration periods and an increase trend in the later restoration period. One-way ANOVA showed significant difference in $\mathrm{KN}$ in the 0 $20 \mathrm{~cm}$ layer, and no significance difference in the $20-40 \mathrm{~cm}$ layer or TN in either layer.

$\mathrm{TP}$ and Olsen-P ranged from $0.046 \%$ to $0.070 \%$ and $5.13 \mathrm{mg} \mathrm{kg}^{-1}$ to $15.99 \mathrm{mg} \mathrm{kg}^{-1}$, respectively, in the $0-20 \mathrm{~cm}$ layer and $0.031-$ $0.037 \%$ and $1.87-5.57 \mathrm{mg} \mathrm{kg}^{-1}$, respectively, in the $20-40 \mathrm{~cm}$ layer (Fig. 4). One-way ANOVA analysis showed no significant difference in
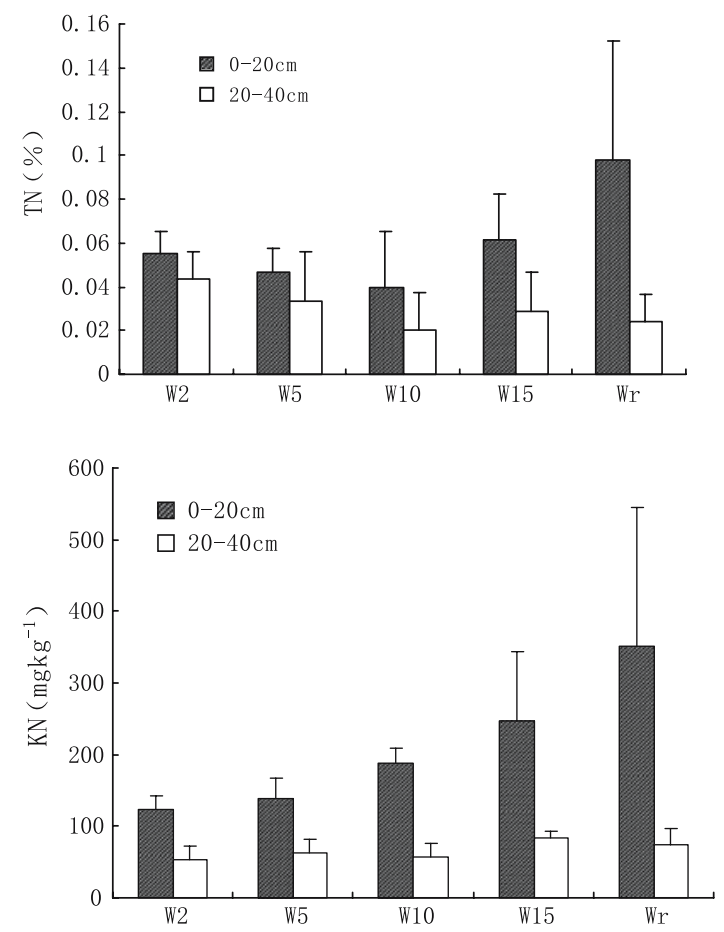

Fig. 3 Changes of soil total $\mathrm{N}$ and $\mathrm{K} \mathrm{N}$ in different restored wetlands
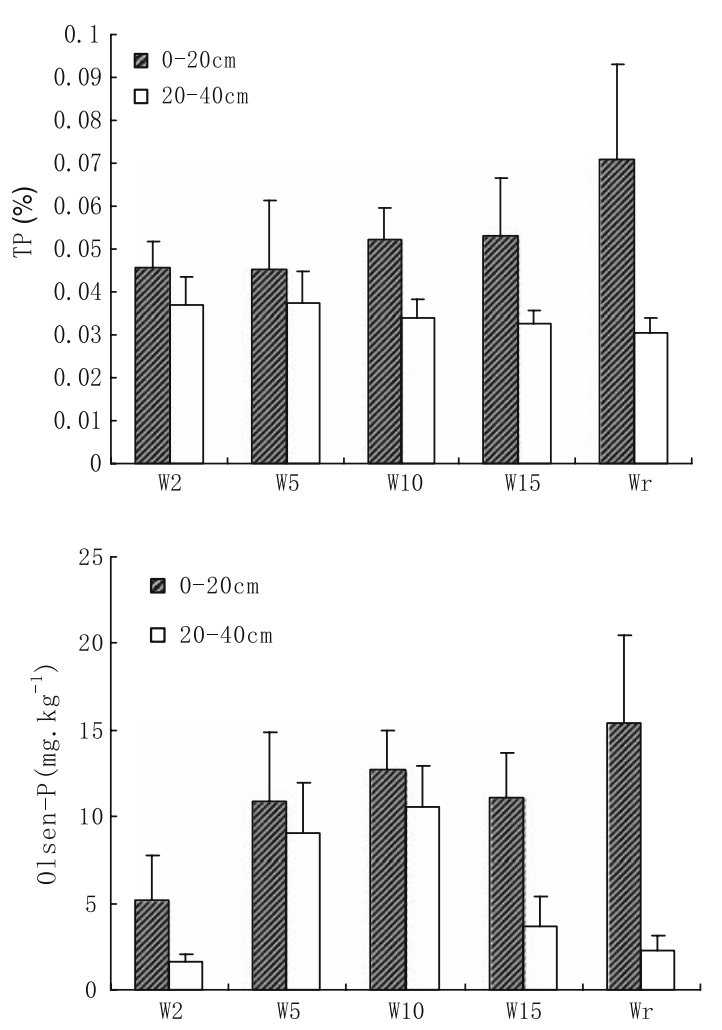

Fig. 4 Changes of total $\mathrm{P}$ and Olsen-P in different restored wetlands

Olsen-P and TP in both $0-20 \mathrm{~cm}$ layer $20-40 \mathrm{~cm}$ layer. The results showed that although the content of TP and Olsen-P indicate an increasing trend, there were no significant change of TP and Olsen-P in restored wetlands in all.

Soil nutrient (TN, TP, TOC, KN, and Olsen-P) concentrations were lower in the $20-40 \mathrm{~cm}$ layer than the $0-20 \mathrm{~cm}$ layer. This indicates that nutrients are stored primarily in recent sediment deposits.

Table 1 Changes of soil bulk density, porosity and water stable aggregate content in different restored wetlands in Lake Taihu, East China

\begin{tabular}{llll}
\hline $\begin{array}{l}\text { Time } \\
\text { abandoned }\end{array}$ & $\begin{array}{l}\text { Soil bulk } \\
\text { density }\end{array}$ & $\begin{array}{l}\text { Soil porosity } \\
(\%)\end{array}$ & $\begin{array}{l}\text { WSA } \\
(>0.25 \mathrm{~mm})\end{array}$ \\
\hline 2 years & $1.06 \mathrm{~g} \mathrm{~cm}^{-3}$ & 59.9 & $20.2 \%$ \\
5 years & $0.87 \mathrm{~g} \mathrm{~cm}^{-3}$ & 71.2 & $30.6 \%$ \\
10 years & $0.74 \mathrm{~g} \mathrm{~cm}^{-3}$ & 72.0 & $44.3 \%$ \\
15 years & $0.74 \mathrm{~g} \mathrm{~cm}^{-3}$ & 72.0 & $54.8 \%$ \\
$\begin{array}{l}\text { Reference } \\
\text { wetland }\end{array}$ & $0.58 \mathrm{~g} \mathrm{~cm}^{-3}$ & 77.9 & $57.1 \%$ \\
\hline
\end{tabular}


Table 2 The species colonized after rice fields abandonment

\begin{tabular}{|c|c|c|c|c|c|}
\hline \multirow[t]{2}{*}{ Species } & \multicolumn{4}{|c|}{$\begin{array}{l}\text { Length of } \\
\text { land } \\
\text { abandonment } \\
\text { (years) }\end{array}$} & \multirow[t]{2}{*}{$\begin{array}{l}\text { Natural } \\
\text { reference } \\
\text { wetland }\end{array}$} \\
\hline & 2 & 5 & 10 & 15 & \\
\hline Phragmites communis & 0 & 1 & 1 & 1 & 1 \\
\hline $\begin{array}{l}\text { Miscanthus } \\
\text { sacchariflorous }\end{array}$ & 0 & 1 & 1 & 1 & 1 \\
\hline Zizania latifolia stapf $\mathrm{L}$. & 0 & 0 & 1 & 1 & 0 \\
\hline Cyperus iria $\mathrm{L}$. & 0 & 0 & 0 & 1 & 0 \\
\hline Eleocharis yakoscensis & 0 & 0 & 1 & 0 & 0 \\
\hline Polygonum amphibium & 0 & 0 & 0 & 1 & 0 \\
\hline $\begin{array}{l}\text { Polygonum perfoliatum } \\
\text { L. }\end{array}$ & 0 & 0 & 1 & 1 & 1 \\
\hline Juncus setchueusis Bush. & 1 & 1 & 0 & 0 & 0 \\
\hline $\begin{array}{l}\text { Murdannia triquetra } \\
\text { (Wall) Bruckn }\end{array}$ & 0 & 1 & 0 & 0 & 0 \\
\hline $\begin{array}{l}\text { Lycopus lucidus Turcz } \\
\text { var. hirtus Regel }\end{array}$ & 0 & 1 & 1 & 1 & 0 \\
\hline Poa апnua & 1 & 1 & 0 & 0 & 0 \\
\hline Poa faberi Rendle & 1 & 1 & 0 & 0 & 0 \\
\hline Glgcine sojasieb et Zucc & 1 & 0 & 0 & 0 & 0 \\
\hline Solanum nigrum & 1 & 0 & 0 & 0 & 0 \\
\hline Setaria viridis (L.) Beauv & 1 & 1 & 0 & 0 & 0 \\
\hline Lactuca indica. L. & 1 & 0 & 0 & 0 & 0 \\
\hline $\begin{array}{l}\text { Artemisia } \\
\quad \text { lavandulaefolia DC }\end{array}$ & 1 & 1 & 0 & 0 & 0 \\
\hline Artemisia annua & 0 & 1 & 0 & 0 & 0 \\
\hline Gynura crepidioides & 0 & 1 & 0 & 0 & 0 \\
\hline Clematis & 0 & 0 & 1 & 0 & 0 \\
\hline Humulus scandens & 1 & 1 & 1 & 1 & 1 \\
\hline Bidens bipinata & 0 & 0 & 1 & 1 & 1 \\
\hline $\begin{array}{l}\text { Cocculus trilobus } \\
\text { (Thrund.) DC. }\end{array}$ & 0 & 0 & 0 & 0 & 1 \\
\hline Rosa cymosa Tratt & 1 & 1 & 1 & 0 & 0 \\
\hline Ampelopsis Michx & 0 & 0 & 0 & 1 & 1 \\
\hline Sapium P. Br & 0 & 0 & 0 & 0 & 1 \\
\hline $\begin{array}{l}\text { Chinese Fevervine } \\
\text { scandens }\end{array}$ & 0 & 0 & 1 & 1 & 1 \\
\hline Total number of species & 10 & 13 & 11 & 10 & 9 \\
\hline
\end{tabular}

Soil texture changes in restored wetlands

Table 1 shows soil bulk density, soil water content, and soil porosity along the succession gradient defined by paddy fields abandoned for $2,5,10$, and 15 years and the natural reference wetland. Soil bulk density ranged from $0.58 \mathrm{~g} \mathrm{~cm}^{-3}$ to $1.06 \mathrm{~g} \mathrm{~cm}^{-3}$ with a decreasing progression with time abandonment. During the wet season, water content increased from $50 \%$ to $300 \%$ along the succession gradient. In the dry season, land that

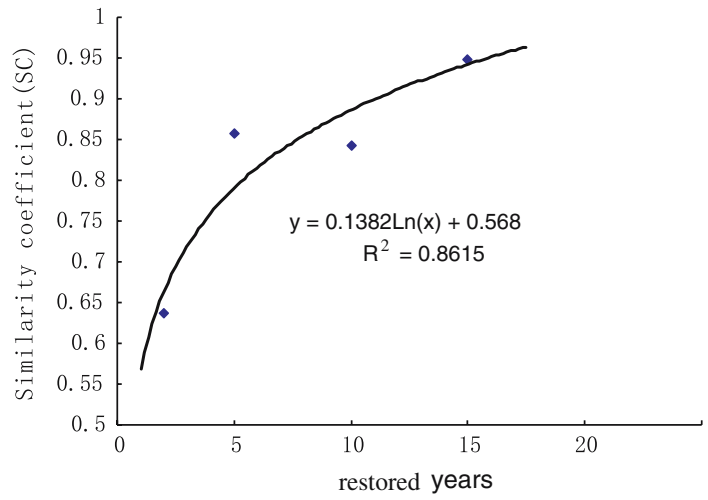

Fig. 5 Similarity coefficient (SC) of vegetation in different restored wetlands

had been abandoned longer had more water than more recently abandoned paddy fields. There also was an increase in soil water stable aggregates $(>0.25 \mathrm{~mm})$ in abandoned paddy fields along the succession gradient, and the proportion of large water stable aggregate at later stages was higher than earlier stages of succession. These results indicate that restoration of abandoned paddy fields improves soil quality and texture.

Vegetation changes in restored wetlands

Dominant plant species changed in the first 10 years after the paddy fields were abandoned (Table 2). In the first 2 years, abandoned land became covered by a plant community dominated by Poa annua, Humulus scandens, Gynura crepidioides, and Glgcine sojasieb. This situation was

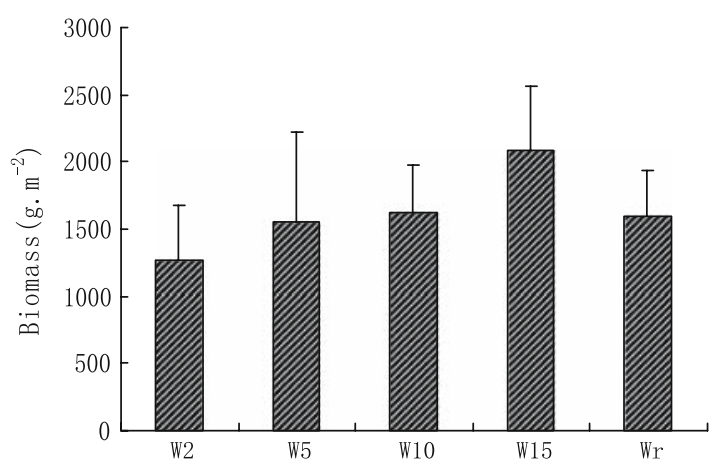

Fig. 6 Changes of vegetation biomass in different restored wetlands 


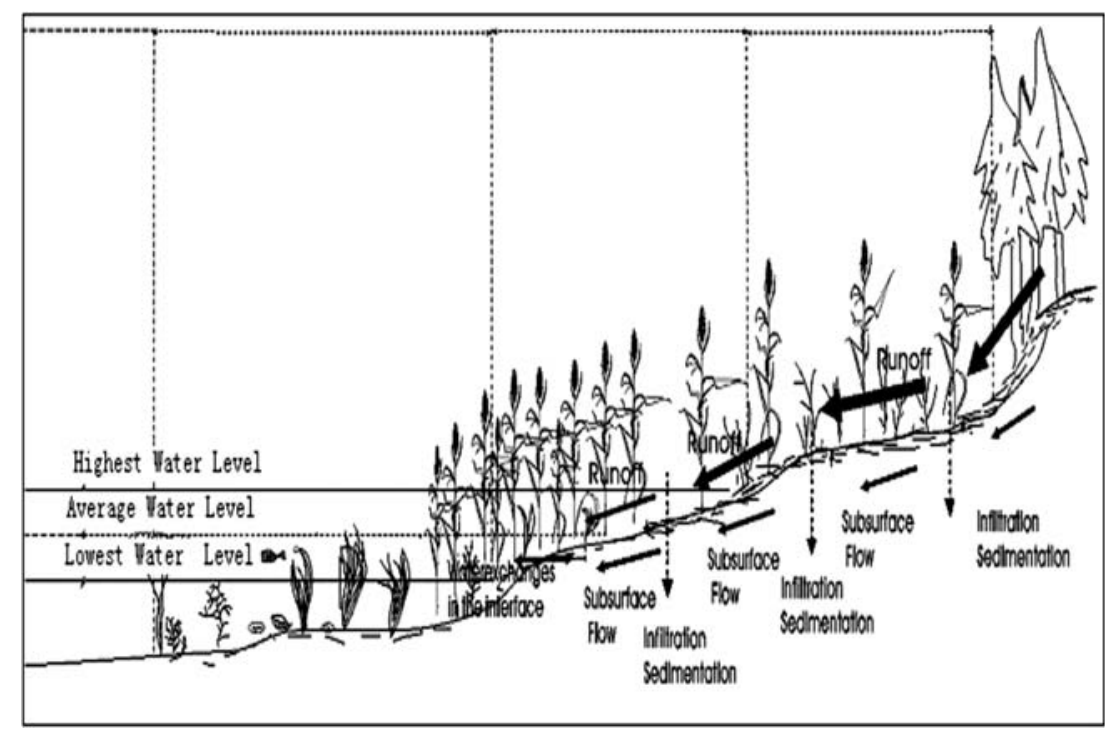

Fig. 7 The sketch map of the function of riparian wetlands

common in most abandoned paddy fields. During the early stage of abandonment (2-5 years), the number of plant species increased from 10 at the 2-year abandonment site to 13 at the 5-year site. Dominant plant species were Humulus scandens, Miscanthus saccharifloous, Lycopus lucidus Turcz, Var. hirlus Regel, Poa annua, and Poa orinosae. At the 5-year site, some wetland species, such as Miscanthus saccharifloous, Zizania latifolia stapf, and Polygonum amphibium, increased significantly, but some annual and biennial species and weeds still existed. After 5 years, some initial annual species, such as Poa annua, Gynura crepidioides, and Glgcine sojasieb declined. The number of species decreased from 13 at 5-years to 10 and 9 in the 10- and 15-year fields, respectively. Species composition after 15 years of abandonment was similar to the reference wetland, and Phragmites communis, Miscanthus saccharifloous, and Zizania latifolia stapf were dominant. SC was 0.64 at the 2-year site and 0.94 at the 15 -year site compared with the reference wetland (Fig. 5). There was a significant relationship between SC and number of years since abandonment $\left(r^{2}=0.8615\right)$. Dry biomass increased from $1270 \mathrm{~g} \mathrm{~m}^{-3}$ to $2100 \mathrm{~g} \mathrm{~m}^{-3}$ over the whole period (Fig. 6). One-way ANOVA showed a significant difference in dry biomass in wetland restoration, although there was no significance difference between W5 and W10. That showed there lay an obvious trend of dry biomass in the wetland restoration process. Plant community changes after land abandonment suggest that vegetation self-regenerates and species diversity recovers by returning paddy fields or lakeshore land to a more natural state.

\section{Discussion}

Riparian zones are critical in maintaining biological connections along environmental gradients (as indicated in Fig. 7). They reduce runoff from upland and increase infiltration; they are a physical buffer to trap sediments and sediment-bound pollutants; they are also a biological buffer to remove nutrients via plant uptake.

Vegetation is important in riparian ecosystems, and wetlands converted from abandoned paddy field showed secondary succession. Height and density of colonized plants increased along the succession series. With longer abandonment time, species composition increased in similarity and stability and reflected functional characteristics of a natural riparian wetland vegetation community. Wetland species, such as Phragmites communis, Miscanthus saccharifloous, and Zizania latifolia stapf dominated in abandoned paddy fields and 
colonized gradually over 15 years. Other plant species may be more competitive in other environments (Cooper et al., 1987). Changes in the similarity index and aboveground biomass indicated an increasing trend during restoration. Comparison of vegetation changes and related indices between restored wetlands showed a general trend towards a mature community or ecosystem, which has also been observed in terrestrial systems (Peng, 1995; Comin et al., 2001). In this study, we observed that groundwater table fluctuation might limit riparian wetland ecosystem succession. In some situations, only a high groundwater table allowed abandoned paddy fields or degraded wetlands to be restored to natural riparian wetlands (Andrew \& Baldwin, 2002; Castelli et al., 2000).

Soil restoration is important to consider in evaluating wetland restoration. Results showed that soil quality improved with time due to accumulation of TOC, TN, TP, and improvement of soil texture. Similar results were reported in terrestrial ecosystems (Browman et al., 1990; Peng, 1995; Kosmas et al., 2000; Comin et al., 2001; Singh et al., 2001; Lee et al., 2002; Bruland \& Richardson, 2004, 2005). Soil $\mathrm{pH}$ in riparian areas ranged from 4.90 to 5.28 in the $0-20 \mathrm{~cm}$ layer and 5.68 to 5.92 in the $20-40 \mathrm{~cm}$ layer in Fig. 5. In this study, TOC, TN, TP, KN, and Olsen-P increased with time and eventually reached similar concentrations to natural, undisturbed wetlands. Recovery of vegetation is key to successful soil restoration.

The results suggest a faster increase for soil TOC, KN, TP and Olsen-P in the early vegetation succession stage followed by a slower rate in later stages, while TN decreased in early stages. Nutrient accumulation probably resulted from decomposition of plant debris and retention of nutrients from upland areas. The recovery of vegetation and litter decomposition result in lower soil $\mathrm{pH}$ during restoration and create a suitable environment for soil C, N, P accumulation. Although nutrient accumulation in riparian restoration may result in leaching into lakes by subsurface flows, it is negligible compared with controlling non-point source pollution (Naiman \& Décamps, 1997).

Low TOC accumulation in the early restoration period mainly was due to high soil $\mathrm{TN}$ concentration, which caused a higher decomposition rate of vegetation litter. The TN decrease early in the succession period may be due to growth of wetland vegetation, high nitrogen fertilizer consumption in the paddy soil before land abandonment, and ammonia volatilization and denitrification. Results also showed that soil TOC, TN, TP, KN, and Olsen-P increased towards levels found in natural wetlands, but restoration of degraded ecosystems likely would need a long time to complete the process. Vegetation restoration in Lake Taihu degraded riparian wetlands probably takes 15 years or more, and restoration of soil characteristics may take more time. In comparison to other ecosystems, restoration of degraded tidal wetlands needs about 6 years (Comín et al., 2001). Craft (2000) suggested that restoration of salt marsh vegetation requires 15 years, and restoration of soil C, N and bulk density needs 25 years. Restoration of degraded pasture may require 30 years (Aronson et al., 1993; Grantz et al., 1998; $\mathrm{Li}, 2003)$. Restoration of degraded forest ecosystems may take 50-100 years (Peng, 1995).

Restored vegetation not only protects surface soil from erosion and improves soil texture, but it also traps nutrient-rich material carried by runoff from uplands to riparian areas. Organic C, N and $\mathrm{P}$ accumulation in soil facilitated dominant wetland species in later succession stages. Vegetation restoration increased the roughness of land and coverage. Improvement in soil texture increases soil porosity and infiltration, facilitates accumulation of soil nutrients, and provides a suitable environment for microbe activity. Implications are that more non-point source pollutants may be treated in restored wetlands. It is expected that, when water level reaches inundation conditions, wetlands still remove pollutants, but is not a pollution source to the lake.

\section{Conclusions}

Changing land use in abandoned paddy fields may exert a profound influence on soil, vegetation, and the environment. With increasing time, vegetation in abandoned fields increased in the maturity of species composition and 
biomass. Results also showed that soil TOC, $\mathrm{TN}, \mathrm{TP}, \mathrm{KN}$, and Olsen-P improved with time. Soil and vegetation facilitated one another in the restoration process. It may take 15 years or more for vegetation and soil characteristics to reach levels in natural wetlands.

Acknowledgments This research was supported by Chinese Academy of Sciences (No. KZCX1-SW-12) and the National Hi-Tech Research Program (No. 2002AA601011-05). We gratefully thank Yaohui $\mathrm{Hu}$, Zexiang Lei, Nian'gen Du and Hongmei Hao for their assistance with sampling and analysis.

\section{References}

Andrew, E. C. \& H. Baldwin, 2002. Responses of wetland plants to ammonia and water level. Ecological Engineering 18: 257-264.

Aronson, J., C. Floret, E. Le Floc'h, C. Ovalle \& R. Pontanier, 1993. Restoration and rehabilitation of degraded ecosystems in arid and semiarid lands. I. A view from the south. Restoration Ecology 1: 8-17.

Browman, R. A., J. D. Reeder \& R. W. Lober, 1990. Changes in soil properties in Central Plain rangeland soil after 3, 20, and 60 years of cultivation. Soil Science 150: 851-857.

Bruland, G. L. \& C. J. Richardson, 2004. A spatially explicit investigation of phosphorus sorption and related soil properties in two riparian wetlands. Journal of Environmental Quality 33: 785-794.

Bruland, G. L. \& C. J. Richardson, 2005. Spatial variability of soil properties in created, restored, and paired natural wetlands. Soil Science Society of America Journal 69: 273-284.

Castelli, R. M., J. C. Chambers \& R. J. Tausch, 2000. Soilwater relations along a soil-water gradient in Great Basin riparian meadows. Wetlands 20: 251-266.

Chen, H. S., 2001. Restoration project of the ecosystem in Lake Taihu. Resources and Environment in the Changjiang River Basin 10(2): 173-178 (in Chinese).

Chen, J. Y. \& S. L. Chen, 2002. Challenges to estuary and shoreline in China. Marine Geology 18(1): 1-5 (in Chinese).

Comin, F. A., J. A. Romero, H. Oliver \& M. Menéndez, 2001. Restoration of wetlands from abandoned paddy fields for nutrient removal, and biological community and landscape diversity. Restoration Ecology 9(2): 201-208.

Coveney, M. F., D. L. Stites \& E. F. Lowe, 2002. Nutrient removal from eutrophic lake water by wetland filtration. Ecological Engineering 19: 141-159.

Cooper, J. R., J. W. Gilliam \& R. B. Daniels, 1987. Riparian areas as filters for agricultural sediment. Soil Science Society of American Journal 51(2): 416-420.
Craft, C., 2000. Co-development of wetland soil and benthic invertabrate communities following salt marsh creation. Wetland Ecology and Management 8(2): 197-207.

Grantz, D. A., D. L. Vaughn, R. J. Farber, B. Kim, L. Ashbaugh, T. VanCuren, R. Campbell, D. Bainbridge \& T. Zink, 1998. Transplanting native plants to revegetate abandoned farmlands in the western Mojave Desert. Journal of Environmental Quality 27: 960-967.

Hu, Y. \& L. G. Jiang, 2004. Returning farmland to lakerestoration of the kidney of Yangtse River. Chinese National Geography 11: 138-146.

Jin, X. S., H. Liu \& Q. Y. Tu, 1990. Lake eutrophication in China. Environmental Sciences Press of China (in Chinese).

Kosmas, C., S. T. Gerontidis \& M. Marathianou, 2000. The effect of land use change on soil and vegetation over various lithological formations on Lesvos (Greece). Catena 40: 51-68.

Lee, C. S., Y. H. You \& G. R. Robinson, 2002. Secondary succession and natural habit restoration in abandoned fields of central Korea. Restoration Ecology 10: 306314.

Li, Y. Q., 2003. Vegetation dynamics and soil characteristics during grassland succession process in abandoned land. MS degree dissertation thesis, Inner Mongolia Agricultural University, $36 \mathrm{pp}$.

Naiman, R. J. \& H. Décamps, 1997. The ecology of interfaces: riparian zones. Annual Review Ecological Systematics 28: 621-658.

Naiman, R. J., H. Décamps \& F. Fournier (eds), 1994. The role of land/inland water ecotones in landscape management and restoration: a proposal for collaborative research. MAB digest 4, UNESCO.

National Bureau of Statistics of China, 2001. Development Report of China in 2001: the ninth five-year plan. Chinese Statistics Press, Beijing, 352 pp (in Chinese).

Peng, S. L., 1995. The restoration and rehabilitation of the degraded ecosystems in the southern part of subtropical China. In Chen, L. Z. \& W. L. Chen (eds), Studies on Degraded Ecosystems in China. China's Science and Technology Publishing House, Beijing, 94-113.

Singh, K. P., T. N. Mandal \& S. K. Tripathi, 2001. Patterns of restoration of soil physicochemical properties and microbial biomass in different landslide sites in the hilly forest ecosystem of Nepal Himalaya. Ecological Engineering 17: 385-401.

Soil Science Society of America and American Society of Agronomy, 1996. Methods of Soil Analysis: Chemical Methods. SSSA Incorporation and ASA Incorporation, Madison, NJ, USA.

Song, Y. C., 2001. The Species Composition of Vegetation Communities. Vegetation Ecology. East China Normal University Press, 62-89.

Tabacchi, E., D. L. Correll, R. Hauer, G. Pinay, A.-M. Planty-Tabacchi \& R. C. Wissmar, 1998. 
Development, maintenance and role of riparian vegetation in the river landscape. Freshwater Biology 40: 497-516.

Vollenweider, R. A., 1992. Coastal marine eutrophication: principles and control. In Vollenweider, R. A., R. Marchetti \& R. Viviani (eds), Marine Coastal Eutrophication, Elsevier Science Publications, 1-20.
Xiong, Z. P., 2004. The analysis for the causes of floods in China and the counter measures for reducing the damage. China Water Resources, 16 pp.

Yin, C. Q. \& Z. W. Lan, 1995. The nutrient retention by ecotone wetlands and their modification for Baiyangdian Lake restoration. Water Science and Technology 32(3): 159-167. 